\title{
Uralkodói múvelődéspolitika és a humanista szöveghagyományozás Megfontolások az erdélyi fejedelmi könyvtár történetének kutatásához
}

A magyarországi humanizmus kutatása az elmúlt években örvendetesen fellendült. Ennek a megélénkülésnek szervezeti és személyi okai is vannak. A Societas Internationalis Studiis Neolatinis Provehendis 2006-ban Budapesten rendezte nemzetközi konferenciáját, amelyet több egyetemi (Szeged, Pécs, Debrecen) rendezvény is kísért. A magyarországi humanizmus latin és görög forrásainak kutatására több szervezett program is működik a Magyar Tudományos Akadémia Irodalomtudományi Intézetében, illetve az említett egyetemeken. Kiemelendő, hogy egy nyelvileg és filológiailag jól képzett új kutatógeneráció tagjai elkötelezett munkával sok nemzetközileg is számontartott eredményt mondhatnak magukénak. A stafétaváltás korszakát éljük tehát, akkor is, ha az idősebbek a jövő kutatási tevékenységének alapköveit teszik le. ${ }^{1}$

Az említett Neo-Latin Kongresszuson Kecskeméti Gábor rövid áttekintést adott a magyarországi és erdélyi humanisták XVI-XVII. századi filológiai tevékenységéről. ${ }^{2}$ Ebben az összefoglalásban a szerző két alapvető jelenséget hangsúlyozott. Az egyik az a tény, hogy a magyarországi és erdélyi humanisták elmélyült, par excellence szövegkiadó filológiai tevékenységet jellemzően nem a hazájukban végeztek, hanem külföldi tanulmányaik során, illetve az egyetemi éveket meghosszabbító időben, Európa több felsőoktatási központjában. A magyarországi és erdélyi kiadások jellemzően iskolai használatra készült szövegválogatások, illetve a magyar nyelvű fordítások. Összegzésének másik alapgondolata az, hogy ezt a tevékenységet

1 Csak egyetlen példa: Riтоóк Zsigmond, Homéros Magyarországon, adalékok (Budapest: Pesti Kalligram Kft., 2019).

2 KeCSKEmÉTI, Gábor, Philological Activities of Early Modern Hungarian and Transylvanian Humanists, in Acta conventus neo-Latini Budapestinensis. Proceedings of the Thirteenth International Congress of Neo-Latin Studies, Budapest, 6-12 August 2006, general ed. Rhoda Schnur, Tempe (Medieval and Renaissance Texts and Studies, 386.) (Arizona: Arizona Center for Medieval and Renaissance Studies, 2010), 343-351. magyarul már korábban megjelent: KeсsкEMÉTI Gábor, Magyarországi és erdélyi humanisták filológiai tevékenysége a 16-17. században, in Classica - mediaevalia - neolatina II., Ladislaus Havas et Emericus Tegrey, eds. (Debrecini: Societas Neolatina Hungarica Sectio Debreceniensis, 2007), 63-71. 
a tanulmányban felsorolt szerzők nem önmagában vett filológiai indíttatásból végezték, hanem a nemzeti nyelvư kultúra megteremtésének szándékával, a közösségnek tett, tudatosan vállalt szolgálatként. Ehhez a gondolathoz kiegészítésképpen egyetlen idézetet közlök. Baranyai Decsi János 1595-ben, a Sallustius-fordításának előszavában több érv mellett azzal indokolja azt, hogy magyarul is szerette volna kézbe adni ezt a római historikust, hogy így köszönje meg Istennek azokat a győzelmeket, amelyeket a török ellen adott:

Vegezetre akaram ezzel az munkaval az en örvendetessegemetis meg mutatnom ahoz az keresztyensegnec gyözedelmehez, mellyet most az kegyelmes Isten hozzanc meg mutatot es naponkent hatalmaval örögbit. Mert miczoda ember vona az, akki az Istennec illyen czudalatos io tétemenyen nem örülne, es örömet küllö keppennis az mint lehetne, meg nem mutatna? Im nem soc idötöl fogva az úr Isten Bokczat, Varsoczot, Faczadot, Lippat, Ienöt, egesz Havaselföldével es Moldovaval az keresztyeneknec kezekben atta, hogy az magyar orszagi gyözedelemröl semmit ne szollyunc. Ki nem czudalkoznec es nem örülne azon, hogy illyen vilag biro feiedelemnec, orszagos hadat az kegyelmes Isten az mi fejedelmünc altal meg vereté, es meg szegyenite, nem külömben mint amaz nagy Goliathot meg veré regen az kis David altal. Mellyekböl mit itilhetünc egyebet, hanem hogy az hatalmas Isten czelekedic az mi feiedelmünc altal az pogansagnac meg vereseben, es az keresztyensegnek szabaditasaban. ${ }^{3}$

Kecskeméti elemzésében ugyanakkor nem tért ki arra a művelődéstörténetileg hangsúlyosan is elemzendő szempontrendszerre, amelyet a humanista tevékenységet folytatók támogatói, az ország mûvelődési politikáját meghatározó személyiségek, tágabban értve a mecénások, a munkákat finanszírozók szándékai határoztak meg. Mostani közleményünk egyik vizsgálati szempontja ez. A másik szempont, amellyel néhány humanista tevékenységét tekintjük, az, hogy a fennmaradt műveik idézetei mennyiben használhatók a gyulafehérvári fejedelmi könyvtár állományának a jellemzésére.

A tizenöt éves háborút joggal tartja a szakirodalom fordulópontnak a magyarországi művelődéstörténetben abból a szempontból, amely a XVI. században bekövetkezett változások irányát illeti. A könyvkiadás nyelvi összetételében határozottan a vernakuláris kultúra irányában történt elmozdulás (az arányokat tekintve) megtorpan, illetve megfordul, a világi kultúra megnyilvánulásait az egyházi jellegúekkel

3 Az Caivs Crispvs Salvstiusnac ket historiaja..., magyarra forditatott Baronyai Detsi Janos altal..., 1596, Hasonmás, tanulmányt írta KuRCz Ágnes (Budapest: Akadémiai Kiadó, 1979). (Bibliotheca Hungarica Antiqua, 10.) (RMNy 786). 
szemben hasonlóan írhatnánk le. Erdélyben - miután az ország hivatalos nyelve a magyar volt, szemben a magyarországi helyzettel, ahol a latin, továbbá mert a XVII. század folyamán kálvinista fejedelmek uralkodtak - ez a tendencia csak később jelentkezett, bár a kultúrának a nyugati államokéhoz képest nézve egyházközelisége folyamatosan megmaradt. Az erdélyi művelődéspolitika egyik fordulópontjának egyik szimbolikus dátuma 1594. Báthory Zsigmond fejedelem ekkor számolt le ellenzékével, fejeztette le azt a politikai elitet, amely személyi összetételében is jelentős akadémita, vagyis egyetemet végzett réteget tudhatott magáénak. ${ }^{4} \mathrm{Az}$ elit változása és ezzel párhuzamosan az ország művelődési intézményeinek fizikai elpusztulása (1593-1606) egy olyan országban, ahol a hatalmi központ aránytalanul nagy gazdasági hatalmat is jelentett a fejedelem és környezete számára, a XVII. század elején egy teljesen új művelődéspolitika kialakítását követelték és tették lehetővé. Bethlen Gábor és I. Rákóczi György élt ezzel a lehetőséggel. ${ }^{5}$ A pusztulás méretét és jellegét egy olyan intézmény történetének felvillantásával jellemeznénk, amely a humanista filológiai munka biztos hátterét szolgáltatta: a fejedelmi könyvtáréval.

A gyulafehérvári fejedelmi udvar ${ }^{6}$ könyvtárának története rövid volt, alig egy évszázados - hiszen 1658-ban a tatárok lényegében felszámolták -, ráadásul csak nagyon keveset tudunk róla. Izabella, Szapolyai János király felesége biztosan vitt

4 Klaniczay Tibor, Értelmiség egyetem nélküli országban, in Uô.: Pallas magyar ivadékai (Budapest: Szépirodalmi Kiadó, 1985), 77-85.; Uô.: Les intellectuels dans un pays sans universités (Hongrie: XVIe siècle), in Intellectuels français, intellectuels hongrois, Béla KöPECZI et Jacques LE GofF, eds. (Budapest-Paris: Akadémiai Kiadó, CNRS, 1985), 99-109. - Fontosnak tartok egy párhuzamra utalást: Az oszmán társadalmi elit kulturális és tudományos szemléletében II. Mehmet (1432-1481) halálától kezdve, végérvényesen pedig II. Bajazid (1447-1512) halálával bekövetkezett változás az egész oszmán emlékezetpolitikát átalakította, abból kiszorítva minden nem iszlám elemet. Cornell H. Fleischer azt a történetet mutatja be, miként nem maradhatott az Amasyából Istambulba költözött, szultánná lett Bajazid (mondjuk) értelmiségi, és ennek a hatalommegtartási technikának milyen könyvtártörténeti vonzatai lettek. Miként kerültek el apja görög kódexei a belső palotából egy másik tárolóhelyre, és persze miként alakult át az udvar értelmisége (Cornell H. FLEISCHER, Learning and sovereignity in the Fifteenth and Sixteenth Century, in Treasures of Knowledge: An Inventory of the Ottoman Palace Library (1502/03-1503/04), Vol. I, Essays, Vol. II, Transliteration and Facsimile „Register of Books” (Kitäb al-kutub, MTA Könyvtára, Keleti Gyújtemény, MS Török F. 59), Gülru NeCIPOĞLu, Cemal KafadAR and Corell H. Fleischer, ed. (Leiden-Boston: Brill, 2019) (Studies and Sources in Islamic Art and Architecture, Supplements to Muqarnas, XIV/I-II.), 155-160.

5 Erdely története, föszerk. KöPECZi Béla (Budapest: Akadémiai Kiadó, 1986), 726-782. (PÉTER Katalin); TARNóc Márton, Erdély múvelödése Bethlen Gábor és a két Rákóczi György korában (Budapest: Gondolat, 1978); BiTSKEy István, „Irodalompolitika Bethlen Gábor és a két Rákóczi György udvarában”, Magyar Könyvszemle, 96(1980): 1-14.; KURTA József Tibor, „Egyház és könyv, I. Rákóczi György művelődéspolitikája", Református Szemle, 94(2001): 72-76.

6 PÁLFFY Géza, Mi maradt az önálló magyar királyi udvarból Mohács után? - KovÁcs András, Gyulafehérvár, az erdélyi fejedelmi udvar szintere a 16 században, in Idôvel paloták ... Magyar udvari kultúra a 16-17. században, G. ETÉNYI Nóra és HoRn Ildikó, szerk. (Budapest: Balassi Kiadó, 2005), 45-59., 235-258. 
magával köteteket a budai könyvtárból, hiszen a Leon Battista Alberti-corvina a Zápolya-könyvtárból került Olomoucba. ${ }^{7}$ Erdély fejedelmei nagy gondot fordítottak az udvari bibliotéka gyarapítására. János Zsigmond az 1560-as években címeres tulajdonjeggyel (supralibros) látta el könyveit, a magyar országos főkapitány, Balassa Menyhárt (1511-1568) titkárának, Bódog Józsának a könyveit 1563-ban a sajátjaihoz soroltatta, a középkori nagyváradi könyvtárak anyaga - az ágostonos rendházé vagy Haczaki Mártoné - is részben az ő gyűjteményét gazdagította. ${ }^{8}$ Könyvei közül azonban csak egy Erasmus-, egy Marcus Antonius Sabellicus- és egy Philippe Commines-kötet maradt fenn, ${ }^{9}$ továbbá Petrus Ramusnak egy dedikált műve, amelyben udvariasan elutasítja a meghívást egy Szászsebesen létesítendő felsőfokú iskola katedrájára. ${ }^{10}$

A váradi könyvanyagot Báthori István a kolozsvári jezsuita iskola számára gyưjtötte össze ideiglenesen a fejedelmi székhelyen. Ugyancsak Jakó hívja fel a figyelmet arra, hogy az a könyvanyag, amely Náprágyi Demeter címzetes erdélyi püspökkel került Győrbe, részlegesen az erdélyi fejedelmi könyvtáré volt, köztük az 1594-ben kivégzett Gyulai Pál gyưjteményéből származó tételekkel. ${ }^{11}$

Biztosan mondhatjuk azonban, hogy a Báthory András fejedelem könyvtáráról fennmaradt árverési jegyzék olyan könyveket sorol fel, amelyek sohasem kerültek Erdélybe. Igaz, Veress Endre egy megjegyzése arra utal, hogy Báthory Zsigmond néhányat kiválasztott:

[Báthory András] Tragikus halálának híre Vármiába is villámgyorsan eljutott s a sors szeszélye úgy akarta, hogy a lemondott Zsigmond fejedelem éppen a heilsbergi kastélyban értesüljön róla, melyet a bíboros, engedett át neki lakásul cserében a fejedelemségért. Báthory Zsigmond erre hirtelen összecsomagolt - s unokabátyja könyveiből is magához vevén néhány értékesebb könyvet, Erdély felé sietett, hogy magának újra biztosítsa.

7 JAKÓ Zsigmond, Erdély és a Corvina, in Uô., Irás, könyv, értelmiség, Tanulmányok Erdély történelméhez (Bukarest: Kriterion, 1976), 176-177.

8 JAKó Zsigmond, Várad helye középkori egyháztörténetünkben - Erdély és a Corvina, in JAKó, Erdély és a Corvina..., 146, 167, 177.

9 JAKó, Uo., 175.; DanKanits Ádám, XVI. századi olvasmányok (Bukarest: Kriterion. 1974), 65-67.; Vö.: Csernus Sándor, „A reneszánsz fejedelemtükrök forrásvidékén: Philippe de Commynes”, Századok, 133(1999): 125-144.

10 Dankanits, XVI. századi..., 12.; Vö. PÁLfI József, Református felsőoktatás Erdélyben, Universitas sors a reformációtól a Kolozsvári Tudományegyetemig (Kolozsvár: EME 2009), 57-69. (itt különösen a Szamosközy hivatkozás figyelemre méltó Szászsebesről a 63. oldalon).

11 JAKó, Várad helye..., 177.; forrásairól: Uo., 338.; Vö.: VÁSÁRHELYI Judit: „A győri Székesegyházi Könyvtár possessorai I., Náprági Demeter könyvtára - II. Az „erdélyi” gyüjtemény”, Magyar Könyuszemle, 96(1980): 117-130., 230-263. 
Az összeírt 207 könyv 1608-ban került árverésre Heilsbergben. ${ }^{12}$

A XVI. század erdélyi kancellárjai (Csáky Mihály, Forgách Ferenc, Sulyok Imre, Kovacsóczy Farkas, Jósika István) mindegyike egyetemet végzett, ${ }^{13}$ és az állam (fiskus) szolgálatában állók jelentős része is képzett (iskolázott) volt. Az 1594. év, a Báthory Zsigmond-ellenes kör említett kivégzése ebből a szempontból is fordulatot hozott. A XVI-XVII. század fordulóján a fejedelmi udvar környezetében élt tudósok, Szamosközy István, Baranyai Decsi János munkái nem születtek volna meg, ha nem támaszkodtak volna egy gazdag gyưjteményre. Ismerjük Szamosközy feljegyzését a Corvináról. Ebben olyan szövegkiadásokat sorolt fel 1598-ban, vagyis nem külföldi tanulmányútján, melyeknél elképzelhetetlen az autopszia hiánya. ${ }^{14}$ Ugyanakkor éppen tőle tudjuk, hogy a Báthory Zsigmond hintapolitikája során keletkezett zavargásokban a fejedelmi könyvtárat is barbárul elpusztították. ${ }^{15}$ Ennek az elpusztításnak a részeként említhető Istvánffy Miklós dokumentumgyưjtése. A derék historikus császári biztosként lehetőséget nyert a fejedelmi könyvtárban való munkára, és könyvtárának története azt bizonyítja, hogy vett magához kéziratokat onnan. ${ }^{16}$ Talán Giovanni

12 VERESS Endre, „Báthory András b. püspök könyvtára”, Magyar Könyvszemle, 30(1905): 1-26. (idézett mondat: 7-8.); Erdélyi könyvesházak III, 1563-1757, A Bethlen-család és környezete, Az Apafi-család és környezete, A Teleki-család és környezete, Vegyes források, sajtó alá rend. MоNOK István, NÉMETH (VISKOLCZ) Noémi és VARGA András (Szeged: Scriptum, 1994) (Adattár XVI-XVIII. századi szellemi mozgalmaink történetéhez, 16/3.), 333-340. (Heilsberg, ma Lidzbark Lengyelországban).

13 Horn Ildikó, A fônemesi iskoláztatás változásai az Erdélyi Fejedelemségben, in Barokk, TörténelemIrodalom-Mũvészet, Különszám, (Warszawa: Wydawnictwo Neriton, 2010), 109-124, 110.

14 „nuperrime in lucem prodierunt” MoNOK István, Nyitott kérdések a Bibliotheca Corviniana kora újkori történetében, in A holló jegyében, Fejezetek a corvinák történetéból, MoNOK István, szerk. (Budapest: Corvina Kiadó, Országos Széchényi Könyvtár, 2004), 45-63.

15 Szamosкözy István, Erdély története (Rerum Transylvanicarum pentades et hebdomades), vál., bev., jegyzetek SinKoviTs István, ford. BoRZsÁK István (Budapest: Magyar Helikon, 1963) (Monumenta Hungarica, 7.), 274. (az 1977. évi kiadásban: 344.)

16 Szamosközy és Baranyai Decsi kéziratait is ő vitte magával. Vö. BALÁzs Mihály-MonoK István, Szamosközy István és a Corvina, Magyar Könyvszemle, 102(1986), 215-219.; BaLÁzs MihályMonoK István, Történetírók Báthory Zsigmond udvarában, in Magyar reneszánsz udvari kultúra, szerk. R. VÁrkonyI Ágnes, (Budapest: Gondolat, 1987), 249-262.; Balázs Mihály-MonoK IstvánVARGA András; TAR Ibolya (ford.), Baranyai Decsi Jánosnak a török elleni háborúra buzdító beszéde 1598-ból, Lymbus, Múvelődéstörténeti Tár, II. (Szeged: Scriptum Kft., 1990), 37-101. (Klny.: A Lymbus Füzetei, 11.); BaLÁzs Mihály-MonoK István; TAR Ibolya (ford.), Az elsố magyar ars historica: Szamosközy István Giovanni Michaele Bruto történetírói módszeréról (1594-1598), Lymbus, Művelődéstörténeti Tár, IV. (Szeged: Scriptum Kft., 1992), 49-86. (Klny.: A Lymbus Füzetei, 27.). Az Istvánffy könyvtárról Berlász Jenő írta az alapvető összefoglalásokat: BERLÁsz Jenő, Istvánffy Miklós könyvtáráról, Az Országos Széchényi Könyvtár évkönyve, 1959, (Budapest: OSZK, 1961), 202-240.; Uô., Ujjabb információk Istvánffy Miklós könyvtáráról, Az Országos Széchényi Könyvtár Évkönyve, 1972, (Budapest: OSZK, 1974), 218-228. Összefoglalóan, teljes bibliográfiával: MonoK István, A múvelt arisztokrata, A magyarországi fônemesség olvasmányai a XVI-XVII. században, (Budapest-Eger: Kossuth Kiadó, EKF, 2012) (Kulturális örökség), 57-64. 
Michele Bruto történeti munkája nemrég Trentóban felfedezett teljes kéziratának elmozdítása is hozzá köthető. ${ }^{17}$

Bethlen Gábornak eszerint gyakorlatilag az alapoktól kellett kezdenie az udvari könyvtár megteremtését. Eredménnyel, hiszen Háportoni Forró Pál Curtiusfordításának jegyzetei nem a kis Fejér megyei faluban, Háportonban készültek, hanem Gyulafehérvárott töltött hosszabb időt munkája közben. Az általa hivatkozott szerzők és kiadások egy gazdag könyvtárat sejtetnek a háttérben. ${ }^{18}$ Forró a fejedelemnek szóló ajánlásában ki is tér a könyvtárra. Dicséri Bethlent, amiért felkarolta a tudományok művelöit, és mert a

deaki tudományokat... nagy kedvel es szeretettel gyamolittya ... Mellyekhez való nagy szeretetit Felséged ezzel-is megmutatta, hogy Gyula Fejervaras székes helyében minden fele bölcs könyvekkel bövölködö bibliothecat emeltetet, mely dologban Felséged az nagy hirrelnével tündöklő Mattyias királynak dicsiretes példáját követte. ${ }^{19}$

Bethlen Gáborról tudott, hogy kedvvel vitt magával könyveket, amikor elhagyta a fejedelmi székhelyt. Milotai Nyilas István erről így emlékezik meg:

magával szekerén válogatót jo könyveket, mint egy kis Bibliothecat hordoz, s-olvassa, mind penigh hogy ollyan nagy szorgalmatossággal szerze itt Gyula Fejer-varban amaz szép Bibliothecat, es hogy mostan-is fó gondgya vagyon az Koenyveknek keresésére, es egyben szerzésére: foeb az Fölséged méltóságos nevére szenteltetet Könyveknek nagy költséggel való ki bocsattatasara. ${ }^{20}$

17 Ez a feltevés pusztán fantáziálás, de a felfedezők közlése szerint a kéziraton Istvánffy megjegyzései olvashatók (ezt ugyan ráírhatta még Gyulafehérvárt is, bár valószínútlen, hogy ideje lett volna erre), tudott továbbá, hogy Istvánffy könyvtárából Dobronoki György, a jezsuita szervező vitt el könyveket Sopronba. A kéziratot a trentói jezsuiták könyvtárában találták. A kézirat felfedezői a közeljövőben számos tanulmánnyal jelentkeznek, az egyik első: Kasza Péter-PEтneházy Gábor, „Ellentétes narratívák fogságában, Gian Michele Bruto és a Rerum Ungaricarum libri”, Magyar Könyvszemle, 102(2021) nr. 4.

18 A citátumok elemzése: MoNoK István, Olvasmánytörténeti forrásaink - értelmiségtörténet, in Az értelmiség Magyarországon a 16-17. században, szerk. Zombori István, (Szeged: Móra Ferenc Múzeum, 1988), 169-181.

19 HÁPORTONI ForRó Pál, Quintus Curtiusnak az Nagy Sándornak, macedonok királyának viseltetett dolgairól irattatott históriája, (Debrecen: 1619), fakszimile kiadás, A jegyzeteket és a tanulmányt írta Monok István, Appendix I, H. F. P. kisebb müvei, összegyüjt. és sajtó alá rend. MonoK István, Appendix II, sajtó alá rend. és a tanulmányt írta LÁZÁr István Dávid, (Budapest: Balassi Kiadó, 1988) (Bibliotheca Hungarica antiqua, 18.). Az idézet a 12 recto folióról való.

20 Speculum trinitatis, Debrecen, 1622 (RMNy 1262); a fejedelemnek szóló ajánlásban, fol. 5verso. Mosolyt keltő érdekességként megemlítjük, hogy ezzel Bethlen bekerült a „mozgó könyvtárak” 
Az elbeszélő források közül csak Szalárdi János históriáját idézzük:

Bibliothecat, különb tudományokhoz tartozó gyönyörüséges jó könyvekkel rakottat, ollyat szerzett vala ugyanazon collegium szükségére, a mellynek is megszerzése sok ezer tallérokban készülhetett. Mellynek gondviselése erős hit alatt egyik ott való káptalan hűségére bizatván, regestrum szerint, a mikor minemú könyveket a mesterek kikívánnak vala, kiadnák ös azokat ismét az ő idejében beszednék szorgalmatosan, minden kár nélkül, mellyre a bibliothecariusnak ugyan fizetés is jár vala. ${ }^{21}$

Tegyük hozzá, hogy hadjáratai idején az elfoglalt helyekről is vitetett könyveket a fejedelmi székhelyre. Tisztában volt a nyomtatott szó erejével, ezért is rendelte Kassára a Nagyszombatban múködő Nicolaus Mollerust, hogy ne csak katolikus iratokat adjon ki (1621). Erről a hadjáratáról hazatérve alapította az erdélyi fejedelmi nyomdát, előbb vegyes (nagyszombati, kassai) betűkből (Mollerus), majd a kolozsvári Meszléni Márton és 1628-tól a sziléziai Jacob Effmurdt által frissített nyomdai készlettel. A nyomda a XVII. századi Erdély legjelentősebb officinájává vált, kiadványai minden bizonnyal a fejedelmi könyvtárat is gazdagították. ${ }^{22}$

Bethlen Gábor könyvei közül csak öt fennmaradt példányról tudunk, ${ }^{23}$ könyvszeretete, karakteres művelődéspolitikája - magyar nyelvű udvari kultúrát kívánt kialakítani, s ehhez az intézményeket is (iskola, könyvtár, nyomda) megteremtette - a kortársak és az utókor historikusai előtt sem volt soha kétséges. Az öt fennmaradt könyvet tartalmilag szemlélve nem meglepő, hogy a fejedelem olvasta őket (Abraham Ortelius földrajzi munkája, Antonio Guevara fejedelmi tükre, felesége temetésén mondott gyászbeszéd [ 2 példány], illetve Alvinczi Péter kassai prédikátor neki dedikált könyve), de közülük három a fejedelem számára készült kötésben, supralibrosával maradt ránk. Hasonlóan igényes kötéseket készíttetett

történetébe. Vö. TомвоR Tibor, „Két adalék a hazai mozgó könyvtárak történetéhez”, Magyar Könyvszemle, 78(1962): 423.

21 SZALÁRdi János Siralmas magyar krónikája, sajtó alá rend. SzAKÁly Ferenc (Budapest: Magyar Helikon, 1980), 95.

22 V. ECSEDY Judit, A könyunyomtatás Magyarországon a kézisajtó korában 1473-1800 (Budapest: Balassi Kiadó, 1999), 123-127.

23 SzABó Károly, „Bethlen Gábor sajátkezű feljegyzése”, Történelmi Tár, 30(1882): 207.; SiKLóssy László: Gyorskocsin Erdélyben, Kutatások, rajzok, emlékezések (Cluj-Kolozsvár, Minerva, 1927) (Pásztortűz könyvtára, 10.), 90-91.; VITA Zsigmond, „Bethlen Gábor könyvtára”, Magyar Könyuszemle, 81(1965): 221-227.; Uô., Bethlen Gábor könyvtára és utasitásai, in Uô., Mũvelődés és népszolgálat (Bukarest, Kriterion Kiadó, 1983), 8-15.; Szentimrei Mihály, „Bethlen Gábor fejedelmi könyvtárának egy darabja Sárospatakon”, Magyar Könyuszemle, 81(1974): 29-39.; KovÁcs Sándor Iván és KulcSÁR Péter, „Bethlen Gábor könyvtárának újabban előkerült darabja”, Magyar Könyvszemle, 85(1969), 376-377. 
második felesége, Brandenburgi Katalin is. ${ }^{24}$ Bethlennek egy könyvéről, egy Bibliáról még tudunk, de azt ajándékba adta Esterházy Miklósnak, Magyarország nádorának. ${ }^{25}$

A Bethlen Gábor által alapított református Collegium Academicum ${ }^{26}$ könyvtárának viszonya a fejedelmi gyüjteményhez nem teljesen tisztázott. Jakó Zsigmond alapvető tanulmányában azt állítja, hogy a fejedelem a saját könyvtárát nyitotta meg az iskola számára. Ezt arra alapozza, hogy az iskolai törvények csak 1656-ban tesznek említést a könyvtárról. Feltevése szerint a két bibliotheca szétválasztása csak 1653 körül történhetett. ${ }^{27}$

I. Rákóczi György könyvtáráról már többet tudunk. Sárospataki családi gyüjteményéről részletesen is írtunk, de Gyulafehérvárott, nem kevésbé, mint nagy elődje, a fejedelmi bibliotékára is gondot viselt. ${ }^{28}$ Amikor 1638-ban megvásárolta Csanaki Máté (1595-1636) Gdańskban maradt könyveit, azokat Sárospatakra vitette, 104 könyvet azonban - amelyek Patakon már megvoltak - bevitetett Erdélybe. ${ }^{29}$ Feltevésünk szerint a könyvek Gyulafehérvárra kerültek, egyházatyák szövegeinek kiadásaival, de főként orvosi és kémiai munkákkal, okkult filozófiai művekkel gazdagítva az ottani gyüjteményt.

A gyulafehérvári udvar 1658-ban ugyanarra a sorsra jutott, mint 1526-ban (illetve 1541-ben) a budai. Szerepét a művelődési és kulturális élet szervezésében a fő́ri udvarok sora vette át. Valamelyik könyvtár - a fejedelmi és a református Collegium Academicumé - egy töredéke, amelyet sikerült Nagyszebenbe menekíteni,

24 Régi magyar könyvkötések VÉGH Gyula színes rajzaiban, (Budapest: Magyar Bibliophil Társaság, 1936), 23.

25 Esterházy Pál hagyatékénak rendezésekor, 1756-ban a negyedrét eretnek könyvek közt írták össze: Biblia Ungarica Gabrielis olim Betlen. Vö. Magyarországi magánkönyvtárak, IV, 1552-1740, sajtó alá rend. BajÁKI Rita, BujDosó Hajnalka, Monok István és Viskolcz Noémi, a mutatót öszszeáll. Zvara Edina (Budapest: OSZK, 2009) (Adattár XVI-XVIII. századi szellemi mozgalmaink történetéhez, 13/4.), 215.; MonoK István-Zvara Edina, Esterhasiana Biblioteca, (Budapest: MTAK, Kossuth, 2020) (Esterházyana), 37, nr. 9.

26 Legújabban lásd PÁlFi 2009, 70-92.

27 SzABó Károly „A gyula-fehérvári Bethlen-féle főtanoda szervezeti szabályzata”, Történelmi Tár, (1879): 797-805. (Ebben valóban nincsen szó könyvtárról, csak a nyomdászról: De typographo); TÖRÖK Pál „II. Rákóczy György ismeretlen iskolatörvénye”, Erdélyi Irodalmi Szemle, (1927): 118-124.; JAKÓ Zsigmond, A nagyenyedi Bethlen kollégium könyvtárának kezdetei és első korszaka (1622-1658). in JAKÓ 1976. 199-208.

28 Legújabban lásd PÁLFi 2009, 92-99.

29 MonoK István, „Csanaki Máté könyvjegyzéke”, Magyar Könyvszemle, 99(1983): 256-262., МоNoK, NÉMETH (VISKOLCZ) és VARGA A., Adattár 16/3, 1994, 181-184.; a könyvanyag elemzésével: Monok István A Rákóczi-család könyvtárai - Bibliotheken der Familie-Rákóczi, 1588-1660 (Szeged: Scriptum, 1996) (A Kárpát-medence koraújkori könyvtárai - Bibliotheken im Karpatenbecken der frühen Neuzeit, I.), 7-29. 
1662-ben a frissen alapított nagyenyedi kollégiumba került ${ }^{30}$ Isaac Basire (16071676) könyveivel együtt. ${ }^{31}$ Basire Angliából menekült Erdélybe, amikor I. Károly királyt (kinek udvari prédikátora volt) kivégezték. Visszaemlékezésében - bizonnyal túlzással - 20.000 kötet gyulafehérvári pusztulásáról beszél. ${ }^{32}$ A nagyenyedi kollégium tékaelnevezései Basiriust konkretizálják (Theca Basirii), ${ }^{33}$ a többi Fehérvárról való könyvet azonban nem.

Az 1590 és 1630 között Erdélyben elkészült fordítások, illetve szövegkiadások többféle interpretációra adnak lehetőséget. Miután Baranyai Decsi János a Sallustius-fordításának előszavában felsorolja azokat a szerzőket, akiknek műveit szívesen adná a magyarul tudó olvasók kezébe, lehet az ezt követő munkát egy humanista koncepció megvalósításának nevezni.

Mostis az Olaszoc, Nemetec, es egyeb nemzetsegec közöt mind Aristotelest, Cicerot, Virgiliust, es minden fele bölcz embereknec irasokat az ü nyelvekre meg fordittyac, es azoknac nagy hasznatis vezik. Azokaert, az mi nemzetünkben levö fö tudos embereknekis igen io volna tisztesseges mulatsagban avagy ideyekben valo dolgoknac historiaiat meg irnioc, avagy Iulius Cesar, Livius, Tacitus, Curtius es egyeb effele bölcz Historicusoknac irasokat magyar nyelvre forditanioc. Ugy tanulnanac eszesseget es ugy tudnac meg böczülleni effele munkakat. ${ }^{34}$

Maga a szerző tehát teljes fordítói programmal rendelkezett, életműve sokrétú, hiszen írt történeti munkát, kiadott szólásgyüjteményt (Erasmus), jogtudományi munkát. Kortársa, Szamosközy István római feliratgyưjiteményt készített, amelyek gyüjtését azok 1593-as kiadása után is folytatta. Vagyis az antik emlékek tudatos feltárása értelmiségi programjuk részét képezte, lett légyen az jogforrás vagy római

30 Herepei János, „Miképpen kerülte el a gyulafehérvári bibliotékának egy része az 1658. évi tatár pusztítást?”, Magyar Könyvszemle, 77(1961): 170-172.; Vö. PÁLFI 2009, 125-127.

31 Erdélyi könyvesházak II, Kolozsvár, Marosvásárhely, Nagyenyed, Szászváros, Székelyudvarhely, sajtó alá rend. MonoK István, Németh (Viskolcz) Noémi és Tonk Sándor (Szeged: Scriptum, 1991) (Adattár XVI-XVIII. századi szellemi mozgalmaink történetéhez, 16/2.), 116-198.; NAGY Gyula, „Adalék Basirius Izsák XVII. századbeli gyulafejérvári tanár könyvtárához”, Magyar Könyvszemle, 8(1883): 258-266.; KROPF Lajos, „Basirius Izsák kéziratainak történetéhez”, Magyar Könyvszemle, 11(1886): 70-71.; GöMÖRI György, „Isaac Basire 1661 utáni magyar kapcsolatairól és könyveiről”, Magyar Könyvszemle, 86(1979), 62-65.; MoNOK István és NÉMETH (VISKOLCZ) Noémi, „Isaac Basire könyvei a nagyenyedi református kollégium könyvtárában (1679-1680)”, Magyar Könyvszemle, 108(1992), 256-264.

32 A marosvásárhelyi kéziratot idézi JAKó Zsigmond, A nagyenyedi Bethlen kollégium könyvtárának kezdetei és első korszaka (1622-1658), in JAKÓ 1976, 207, 343.

33 Monok-Németh (Viskolcz)-Tonk S., Adattár 16/2, 1991, 188, 201-202.

34 Lásd harmadik idézett (BARANYai DeCsi-KurCZ, Az Caivs Crispvs Salvstiusnac..., 1979) kiadás előszavát. 
kori felirat. A Baranyai Decsi által felsorolt szerzők közül azonban csak Curtius Rufus Nagy Sándor-életrajzát fordíttatta le Bethlen Gábor, a már említett Háportoni Forró Pállal. ${ }^{35} \mathrm{~A}$ fejedelmek ugyanis a könyvtár gazdagításával, az általuk vagy közvetlen tanácsadóik által fordításra kiszemelt művek kiválasztásával nem filológiai célokat követtek. Sokkal inkább a hatalmi reprezentáció eszközéül szánták ezt a fajta tevékenységet. Bethlen Gábor és I. Rákóczi György is számos ifjú külföldi tanulását támogatta, és uralkodásuk idején sorra jelentek meg olyan könyvek is, amelyeket ők fordíttattak le. Ezek azonban alapvetően az általuk is szorgalmazott új kultuszokhoz kötődtek. Bethlen Gábor például Nagy Sándor és Corvin Mátyás példájának kiemelésével - egyes leírások szerint a tróntermének falkárpitjain is az ő életük eseményeit ábrázolták - saját erejét, politikai programjának üzenetét hangsúlyozta. A Curtius-kiadás is ezért készülhetett el, csakúgy, mint a Mátyás királyról szóló történet kiadása is. I. Rákóczi György Marcus Aurelius példájának felmutatásával - hiszen ő fejeztette be Antonio Guevara Horologium principum címủ munkájának a fordítását ${ }^{36}$ - hasonló szándékból cselekedett, és az a tény, hogy a 17. század első felében megjelent magyar fordítások jellemzően 16. század végi, illetve kortárs erkölcsfilozófusok mủvei voltak, vagy az aktuális hitvitákhoz szükséges közel kortárs európai szerzők munkái - és nem 1500 előtti szövegek -, semmit nem von le a teljesítmény értékéből.

\section{Résumé}

L'objectif de notre communication est de présenter quelques aspects négligés de l'activité humaniste hongroise, définis par les intentions des protecteurs des humanistes et des différentes personnalités déterminant la politique culturelle du pays, dans un sens plus large, par les intentions des mécènes finançant le travail des humanistes. Nous examinerons également dans quelle mesure les citations des œuvres survivantes de quelques humanistes peuvent être utilisées pour décrire le fonds de la bibliothèque princière de Gyulafehérvár.

35 Lásd a 19. jegyzetet (MoNoK-Lázár I. D., kiad., Háportoni Forró..., 1988).

36 A fordítás Prágai András munkája. Bártfa, 1628 (RMNy 1400) 